\title{
ECOLOGICAL AND ENGINEERING IMPORTANCE OF THE BET EL RAS BEACH-SANDSTONE
}

\author{
N Nyandwi ${ }^{1}$ and JW Kangwe ${ }^{1,2}$ \\ ${ }^{1}$ Institute of Marine Sciences, University of Dar es Salaam, P.O Box 668, Zanzibar, Tanzania. \\ ${ }^{2}$ Tanzania Fisheries Research Institute, P. Box 9750, Dar es Salaam, Tanzania. \\ Email:nyandwi@ims.udsm.ac.tz; kangwe@ims.udsm.ac.tz
}

\begin{abstract}
A unique sandstone known as the Bet el Ras sandstone, supposedly of Holocene age, occurs profusely along the western coast of Unguja but more extensive at its locality area, Bet el Ras, where it forms a rocky shore. The sandstone has been blasted in the past for construction of the sea wall that fronts the Zanzibar Town, and stands to be blasted further for renovation works. From the results of the survey made, it is clear that the sandstone is ecologically and environmentally important such that its total removal will lead to loss of a habitat as well as enhance coastal erosion and sediment input in the littoral zone thereby impacting on the ecology of the associated flora and fauna. Since none of the fauna species is endemic and due to its engineering importance, selective extraction may be considered such that extraction of the sandstone be done in steps and cavities be refilled as well. A thin veneer may also be left close to the land as protection against erosion. This will also minimize sediment input in the littoral zone that would otherwise have affected the community structure.
\end{abstract}

\section{INTRODUCTION}

The Bet el Ras beach lies on the western side of Unguja Island, which is more varied geographically and geologically than the eastern side. Unguja Island is one of Tanzania's major islands, the others being Pemba and Mafia. Unguja and Mafia islands are part of inner shelf, which became uplifted during Tertiary times (Kent et al. 1971). They are both separated from the mainland by shallow channels, less than 50 $\mathrm{m}$ deep.

Unguja Island, which is about $85 \mathrm{~km}$ long and $35 \mathrm{~km}$ wide, is elongated in the NorthSouth direction with a strong North-South lineation in its physical features. The island extends between latitudes $5^{\circ} 46^{\prime} 30^{\prime}, \mathrm{S}-6^{\circ}$ $28^{\prime} 59^{\prime \prime} \mathrm{S}$ and longitudes $39^{\circ} 12^{\prime} 00^{\prime \prime} \mathrm{E}-$ $39^{\circ} 34^{\prime} 41^{\prime \prime}$ E. The island is presumed to be a result of submergence of the shallow intervening channel (Stockley 1928, Kent et al. 1971, Shaghude 2001, Shaghude et al. 2002, Muzuka 2003). The island has a core of sedimentary rocks of Miocene-Pliocene age, closely related to similar rocks on the mainland and surrounded by recent reefal limestone which occupies the whole eastern and southern half of the Island (Hoyle 1967). The oldest outcropping rocks that have been found on the Island are of lower Miocene known as the Masingini beds. The Masingini beds are predominantly marly sands with subordinate limestone, greyish when fresh, weathering to reddish-brown sandstone partly oxidized on the hill faces (Kent et al. 1971, Muzuka 2003). The beds dip eastward at an angle of $2^{\circ}$ to $5^{\circ}$ but there are western dips along the coast (Kent et al. 1971, Muzuka 2003). Pliocene rocks are rare and are only found on the Tumbatu Island. In many areas the Miocene rocks are overlain by limestone rocks of Pleistocene age. The Pleistocene-Holocene consists of coral and molluscan remains, and rest unconformably upon the rocks of the Miocene age and indicates that in Pleistocene times the sea level was relatively much higher than at the present day (Muzuka 2003). A unique sandstone known as the Bet el Ras sandstone, supposedly of Holocene age, occurs profusely along the western coast of Unguja but more extensive at its locality area, Bet el Ras, where it forms a rocky 
shore. The sandstone has been blasted in the past for construction of the sea wall that fronts the Zanzibar Town.

Rocky shores exist where the effect of waves on the coastline is mainly erosive, wearing down the softer materials and carrying them away, leaving the hardest rocks exposed (Tait 1980). Most of the substrate is therefore stable and permanent, forming a secure surface upon which a variety of organisms requiring attachment can grow; for example large algae, barnacles, mussels, limpets and oysters (King 1972). The appearance of the shore depends largely upon the type of rock exposed. Horizontal strata often erode to a stepped series of fairly uniform level platforms which provide little shelter against waves. Tilted strata running across the shore usually produce a very varied shore with numerous protruding rock ledges and overhangs, and deep pools in the gullies between them. Certain types of rock erode to a smooth surface, while some laminated rocks readily gape to form deep narrow fissures.

Zanzibar being a historical town, efforts are being made to preserve the architecture in renovation works. The seawall fronting much of the old part of the town locally known as the stone town was built of the Bet el Ras sandstone. Now that the seawall requires rehabilitation, the existing beach sandstone stands once again for blasting. It is suspected that if the sandstone is removed, the remaining shoreline may undergo rapid erosion leading to increased sedimentation of the foreshore with some impact on the ecology of the associated flora and fauna. It is suspected also that the sandstone must be home to unique organisms that may be lost if the rock was removed. Therefore, this study aims at giving a detailed ecological assessment of the fauna and flora along or within the sandstone and potential environmental consequences if the sandstone was extracted. The present study examines the role and the importance of the sandstone to a variety of living organisms and beach stability, its functional relationship with the adjacent living seagrass beds and advises on the sustainable extraction of the sandstone to avoid enhanced erosion on the beach and mass killing of flora and fauna.

\section{STUDY AREA}

Bet el Ras sandstone (rocky shore) in the Zanzibar Town extends about $1.5 \mathrm{~km}$ from KMKM area southwards close to the fuel reserve tanks (Fig. 1) with an average width of $26 \mathrm{~m}$ from lowest to highest water mark of spring tides. The sandstone is a hard beach rock occupying much of the supratidal zone (above the highest water mark). Environmentally, the rocks seem to be important for protecting the backshore (land) from being eroded by breaking waves during high tide. Ecologically they are important for harbouring some marine organisms such as the oysters, crabs, molluscs and other rock dwellers, which use such substratum for shelter and nursery grounds. The shore is a high energy environment due to strong wave activity that makes the waters turbid around the lowest water mark (LWM) which makes difficult to observe organisms underneath in a normal snorkelling operation. However, most of the organisms found are well protected from predators and other natural disturbances.

\section{MATERIALS AND METHODS Underwater visual count}

Underwater assessment was conducted using visual census technique. This is a rapid, non destructive and low cost technique used for assessment of fauna to provide baseline data for zoning, monitoring and management (English et al. 1994). Sampling stations were established every 50 metres along the sandstone (Fig. 1). At each station, two line intercept transect (LIT), 10 metres apart and $50 \mathrm{~m}$ long were laid underwater perpendicular to the shore from lowest water mark (LWM) seawards across the seagrass meadows. The observer swims slowly holding a T-piece parallel to the substratum along each $50 \mathrm{~m}$ transect counting and 
recording animals encountered within 1 metre coverage on either side (left and right) of the transect line. The mean number of animals counted from the two transects was obtained. The surfer programme (Keckler 1995) was used to plot the sampling sites indicated on figure 1 .

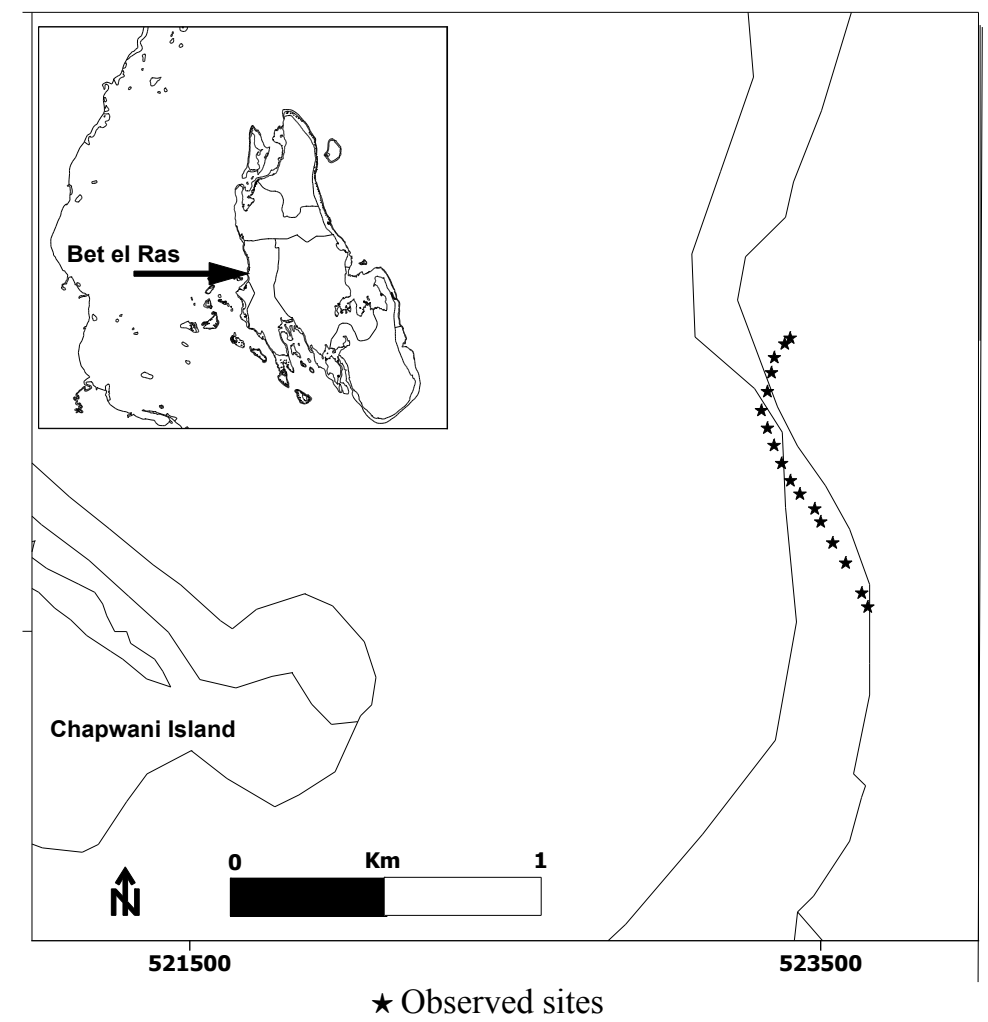

Figure 1: Map showing the position of the study area (Bet el Ras) and sampling sites established every $50 \mathrm{~m}$ along the sandstone using Global Positioning System (GPS).

\section{Flora and fauna assessment within the} sandstone

To assess the abundance and distribution of flora and fauna within the sandstone, a combination of quadrat and rapid visual census was used (to accommodate the mobile organisms such as crabs that cannot be caught in a quadrat). This was carried out by assessing six $1 \mathrm{~m}^{2}$ quadrats thrown at random within an area of $10 \mathrm{~m} \times 10 \mathrm{~m}$ after every $50 \mathrm{~m}$ interval along the sandstone. At each site, ground truthing on percentage cover consisted of counting individual organisms within six $1 \mathrm{~m}^{2}$ metal frames (divided into 100 squares each representing $1 \%$ ) thrown at random. The mean percentage cover from the six quadrats was quantified and taken as a representative value for individual percentage cover at each station. The number of individual crabs, fish and others were counted through visual census and recorded.

\section{RESULTS}

Flora and fauna assessment seawards from the sandstone

During underwater visual census operation, it was found that, seagrasses covered a strip 
of around 25-30 $\mathrm{m}$ wide running from south to north within shallow depths (1.5-2.5 meters), $10-15 \mathrm{~m}$ offshore from the LWM (depending on the slope). Abundant Syringodium species mixed with Thallasia and Thellasodendron species were the most dominant, with Thellasodendron growing in large mats carpeting the whole bottom.

It was further observed that, beyond the seagrass meadow towards deeper waters, the bottom was composed of black fine muddy sediment with some holes, indicating presence of animal activity (such as crabs and mud skippers). Moving towards the northern extremities (the northern end of the teachers college buildings) Syringodium and Thallasia dominates the area with some sparsely distributed Halodule species. Thallasia cover became reduced further from the LWM (about 40-45 m). In the middle of the area from the LWM, thick layers of black muddy sand is found before and after the seagrass strip with many holes, again indicating animal activity. Encountered animals included seaurchins, seastars, crabs, sea cucumbers and some fishes. Table 1 shows the number of animals recorded during underwater observation at 18 stations established (Fig 1).

Table 1: $\quad$ Mean number of animals recorded during underwater visual census at Bet el Ras from two $50 \mathrm{~m}$ line intercept transects at each station.

\begin{tabular}{ccccccc}
\hline Station & Crabs & Seaurchin & Fishes & Seastars & Seacucumbers & Gastropods \\
\hline 1 & 11 & 6 & 4 & 0 & 0 & - \\
2 & 7 & 4 & 7 & 0 & 1 & - \\
3 & 9 & 1 & 2 & 1 & 0 & - \\
4 & 5 & 0 & 6 & 0 & 0 & - \\
5 & 8 & 2 & 3 & 3 & 1 & - \\
6 & 12 & 0 & 5 & 0 & 0 & - \\
7 & 7 & 5 & 1 & 0 & 2 & - \\
8 & 9 & 1 & 4 & 1 & 0 & - \\
9 & 6 & 0 & 0 & 0 & 0 & - \\
10 & 3 & 2 & 9 & 4 & 0 & - \\
11 & 1 & 0 & 1 & 0 & 1 & - \\
12 & 10 & 7 & 8 & 0 & 0 & - \\
13 & 5 & 2 & 1 & 2 & 0 & - \\
14 & 3 & 11 & 4 & 0 & 0 & - \\
15 & 8 & 8 & 2 & 1 & 0 & - \\
16 & 4 & 0 & 0 & 2 & 0 & - \\
17 & 0 & 3 & 0 & 0 & 0 & - \\
18 & 6 & 7 & 9 & 4 & 0 & \\
\hline
\end{tabular}

Flora and fauna assessment within the sandstone

It was observed that, the number of crabs found on the sandstone was much higher than those counted underwater. Although the oysters appear to occupy a higher percentage of the sandstone (Table 2), it was observed that more than $80 \%$ were dead leaving behind their calcareous shells. The number of molluscs counted per square metre was also high on the sandstone compared to the underwater areas. No endemic species was recorded in both operations. 
Table 2: $\quad$ Percentage cover and number of animals recorded within the sandstone at Bet el Ras using combined rapid visual census and quadrates methods.

\begin{tabular}{|c|c|c|c|c|c|c|}
\hline Station & $\begin{array}{l}\text { \% cover of } \\
\text { Sandstone }\end{array}$ & $\begin{array}{l}\text { \% cover of } \\
\text { sand/course } \\
\text { aggregates }\end{array}$ & $\begin{array}{c}\text { \% cover of } \\
\text { Oysters on } \\
\text { the Sandstone }\end{array}$ & $\begin{array}{c}\text { Number of crabs } \\
\text { (within a } 10 \times 10 \\
\text { m area) }\end{array}$ & $\begin{array}{c}\text { Mean } \\
\text { number of } \\
\text { gastropods } \\
\left(\mathrm{m}^{2}\right)\end{array}$ & $\begin{array}{c}\text { Algal } \\
\text { assemblage }\end{array}$ \\
\hline 1 & 40 & 60 & 37 & 8 & - & - \\
\hline 2 & 85 & 15 & 49 & 12 & 5 & - \\
\hline 3 & 40 & 60 & 20 & 7 & 88 & - \\
\hline 4 & 65 & 35 & 45 & 13 & - & - \\
\hline 5 & 60 & 40 & 55 & 9 & - & - \\
\hline 6 & 50 & 50 & 35 & 10 & - & - \\
\hline 7 & 50 & 50 & 35 & 6 & - & - \\
\hline 8 & 50 & 50 & - & 12 & 112 & - \\
\hline 9 & 50 & 50 & - & 18 & 97 & $\mathrm{~F}$ \\
\hline 10 & 65 & 35 & - & 14 & 74 & $\mathrm{~F}$ \\
\hline 11 & 80 & 20 & 2 & 11 & 23 & - \\
\hline 12 & 75 & 25 & 1 & 16 & 36 & $\mathrm{~F}$ \\
\hline 13 & 90 & 10 & 40 & 21 & 21 & - \\
\hline 14 & 90 & 10 & 30 & 13 & - & - \\
\hline 15 & 95 & 5 & 35 & 9 & 11 & - \\
\hline 16 & 95 & 5 & - & 17 & 6 & - \\
\hline 17 & 40 & 60 & 25 & - & 49 & - \\
\hline 18 & 95 & 5 & 15 & 13 & 16 & - \\
\hline
\end{tabular}

\section{DISCUSSION}

Rocks present a variety of habitable environments; exposed rock faces, sheltered overhangs, crevices, deep or shallow pools, silt within fissures or under boulders, in the shelter of algae or in their ramifying holdfast, each offers a domain which some species can occupy (Bergman et al. 2000). The size and composition of rocky shore communities is mostly influenced by the intensity of wave action (Stephenson and Stephenson 1972), for example, the amount and type of algal growth. Where wave intensity is moderate, large algae cover the shore and give shelter to many small animals, which cannot tolerate complete exposure to air and sun, for example coelenterates, sponges and small crustaceans. Stronger waves prevent the growth of plants, and the rocky surface becomes covered mainly with barnacles, oysters and limpets, or sometimes at lower levels by mussels (King 1975). In extreme conditions of wave exposure (like Bet el Ras sandstone), rock faces are swept virtually bare and the population is restricted to fissures and crevices. Because of the wetting effects of splash, heavy wave action tends to raise the levels to which sublittoral and littoral populations extend up the shore, and greatly increases the width and height of the littoral fringe. Where sand is deposited between rocks, their lower parts may be kept bare by the scouring effects of wave-tossed sand

In studying community structure of the sandstone at Bet el Ras, we directly relate to the rocky shores that have proven to be the most versatile habitats, owing to their accessibility to observation and to the strong physiological gradient, ranging from fully marine to terrestrial habitats (Tait 1980). The physiological gradient makes it relatively easy to see the interactions of physiological performance, competition and interspecies interactions (Tilman 1994). Ecological processes such as competition and predation are strongly modulated by the time organisms are exposed to air and such effects cause vertical gradients in the 
importance of, for example, predation (Bergman et al. 2000). Many carnivores can only move about and seize prey when covered with water, which limits the time that intense predation can occur in the high intertidal. The present results on the flora and fauna in the area shows a limited habitation possibly caused by both anthropogenic (Kangwe 1999) and natural (physical and biological) factors (Zieman 1976). The observed mortality of oysters and small number of other organism may be directly caused by pollutants coming from the nearby oil reserve tanks/discharge terminal. Oil spills can severely affect the animal population in an exposed shore leading to killing of the less tolerant individuals (Pastorak and Bilyards 1985). Nevertheless, the changing monsoons (Newell 1959) resulting in change in direction of oil traces dispersal coupled with the fact that oil discharged is only sporadic seem to give window to some growth. The low density of animals obtained in this area indicates that several factors are operating to structure the population. For example, the observed exposure to high wave energy and high tidal range can change the habitat structure and become unsuitable for animal life (Zieman 1976). Food availability and predation can be other factors that may lead to the observed situation (Hay et al. 1988). However, the presence of a continuous strip of healthy seagrass parallel to the sandstone reflects the presence of nutrient input in the area, brought by the enhanced mixing of water due to high wave energy. If the sandstone is removed, the erosion of the remaining shoreline may lead to increased sedimentation of the foreshore with some impact on the ecology of the associated flora and fauna.

\section{CONCLUSION}

It is clear that the sandstone is ecologically important for flora and fauna. It also provides an important physical environment especially with regard to its strength against wave action and erosion. Its total removal therefore, will lead to loss of a habitat and may also enhance coastal erosion and sediment input in the littoral zone.

The loss of the ecological richness of the sandstone and the adjacent waters may, however, be considered acceptable because it contains no endemic species that will be lost from Zanzibar by way of removal of the sandstone. In addition the sandstone is not a healthy and rich habitat especially for oysters.

It is suggested therefore that extraction of the sandstone be done in steps and cavities be refilled as well. A thin veneer may also be left close to the land as protection against erosion. This will also minimize sediment input in the littoral zone that would otherwise have affected the community structure.

\section{REFERENCES}

Bergman K, Öhman MC and Svensson S 2000 Influence of habitat structure on the abundance of Pomacentrus sulfurous, a western Indian ocean reef-fish. Env. Biol. Fish. 59: 243-252.

English S, Wilkinson C and Baker V 1994 Survey Manual for Tropical Marine Resources. ASEAN-Australia Marine Science Project: Living Coastal Resources.

Hay ME, Paul VJ, Lewis SM, Tucker J and TrindeRN1988 Can tropical seaweeds reduce herbivory by growing at night? Diel patterns of growth, nitrogen content, herbivory, and chemical versus morphological defenses. Oecol. 75: 233245.

HoyleBS 1967 The Seaports of East Africa - A geographical study. East Africa Publishing House, Nairobi.

KangweJW 1999 The Effect of Land-based Pollution on the Reef building Calcareous algae in the Reefs near Zanzibar Town. MSc Thesis, University of Dar es Salaam. 107 pp.

KecklerD 1995 Surfer for Windows. Copyright Golden Software Inc. 
Kent PE, Hunt JA and Johnstone DW 1971 The Geology and Geophysics of Coastal Tanzania. HMS Stationery Office, London.

King CAM 1972 Beaches and Coasts. $2^{\text {nd }}$ Edn, Arnold, London.

King CAM 1975 Introduction to Physical and Biological Oceanography. In: Tait RV (ed) Elements of Marine Ecology. An introductory course $3^{\text {rd }}$ edn, Arnold, London

Muzuka ANN 2003 Heavy minerals distribution on the west coast of Unguja and Pemba Islands. University of Dar es Salaam, Institute of Marine Sciences. MARG - 1 Final report - Research report No: IMS/2003/01.

NewellBS 1959 The hydrography of the British East African Coastal Waters. Part II. Colonial Office Fishery Publication, No. 12 H.M.S.O. London

Pastorak RA and Bilyard GR 1985 Effects of sewage pollution on coral-reef communities. Mar. Ecol. Prog. Ser. 21: 175-189.

Stephenson TA and Stephenson A 1972 Life between Tidemarks on Rocky Shores. Freeman, San Francisco.
Tait RV 1980 Elements of Marine Ecology. An introductory Course. $3^{\text {rd }}$ edn, Arnold, London

Tilman D 1994 Competition and biodiversity in spatially structured habitats. Ecol. 75: 2-16.

Shaghude YW 2001 Shallow water carbonate basin of the Zanzibar channel. Ph. D Thesis, Department of Geology and Geochemistry, Stockholm University, Sandlund \& Co Grafiska, Stockholm, pp. 27.

Shaghude YW, Wannas KO and Mahongo SB 2002 Biogenic Assemblage and Hydrodynamic Settings of the Tidally Dominated Reef Platform Sediments of the Zanzibar Channel. West. Ind. Ocean J. Ma. Sci. 1(2): 107 - 116.

Stockley GM 1928 Report on the Palaeontology of the Zanzibar protectorate. The Government of Zanzibar, 180p.

Zieman JC 1976 The ecological effects of physical damage from motorboats on turtlegrass beds in Southern Florida. Aq. Bot. 2: 127-139 